\title{
Rubens. Pensamiento estoico y PINTURA POÉTICA. El juicio de Paris. Una alegoría del mal gobierno. Las tres gracias. Imagen de la liberalidad
}

\author{
Jose María GonzÁlez de Zárate
}

Universidad del País Vasco

Resumen: «Rubens. Pensamiento estoico y pintura poética» trata de presentarnos la figura de Rubens según la definición de Bardon, es decir, como un pintor de la metáfora. Así, sus figuras responden a una lectura más profunda, al «otro hablar» que diría Boccaccio. En este sentido hemos tomado dos ejemplos entre su producción artística. Por un lado las Tres Gracias donde, con un criterio estoico se trata de significar uno de los dos valores que por la tríada conocemos, la liberalidad que ya describe Alberti en su tratado. El Juicio de Paris quiere, siguiendo a mitógrafos tan señalados como Conti y a varios emblemistas de la época, hablarnos de la elección sensual que lleva al mal gobierno. Por otra parte, más monarquías europeas justificaban sus orígenes en los herederos de Príamo, y Paris fue uno de ellos.

Palabras clave: Rubens, Juicio de Paris, Tres Gracias, liberalidad, mal gobierno.

AbSTRACT: «Rubens. Stoic thought and poetic painting» deals with the figure of Rubens defined by Bardon, i.e. as a painter of the metaphor. Thus, his figures respond to a deeper reading, «another way of speaking» Boccaccio would say. In this regard, we have taken two examples among his artistic production. On the one hand, The Three Graces, which using a stoic criterion- is about the significance of one of the two values that we know through the triad: liberality, already described by Alberti in his treatise. The Judgement of Paris, following Mythographers such as the well-known Conti and several emblemistas of the time, intends to speak to us of the sensual choice that leads to bad government. On the other hand, most European monarchies justified its origins in the heirs of Priam, and Paris was one of them. 
Keywords: Rubens, Judgement of Paris, Three Graces, liberality, bad government.

$\mathrm{E}$ n el comentario que realizamos sobre «Algunas pinturas en el Museo del Prado» establecíamos, siguiendo a Baltasar Gracián, una clara distinción entre el ver y el mirar. Y así, si el ver responde a un ejercicio físico, por el mirar entendemos una consideración singularmente del intelecto. Nos decía:

[...] va grande diferencia del ver al mirar, que quien no entiende no atiende; poco importa ver mucho con los ojos si con el entendimiento nada, no vale el ver sin el notar.

Seguíamos a Boccaccio al considerar su propósito en la genealogía de los dioses paganos donde nos dice que el mito esconde variados y múltiples significados que superan una mera lectura literal; vienen a ser metáforas, es decir, tras su consideración epidérmica podemos considerar otro hablar, una lectura que nos lleva a planteamientos intelectuales con marcados significados, especialmente de orden moral. Con ello, los pintores y artistas tuvieron un recurso para explicar por imágenes aspectos singularmente doctrinales muy conformes, en la edad del Humanismo, con el pensamiento cristiano.

En consecuencia, este vocabulario visual, su imaginario -hoy claramente poético-, fue muy divulgado y los Hieroglyphica, libros de emblemas, así como la iconología se convirtieron uno por uno y, en ocasiones, todos ellos en su conjunto, en un recurso visual y semántico para los artistas. ${ }^{1}$

Este planteamiento podemos considerar en el pintor flamenco Pedro Pablo Rubens y, entre otros ejemplos, en el conocido Juicio de Paris, argumento que el artista compuso en varias ocasiones. Así, nos encontramos con dos lienzos elaborados hacia 1625 y 1636 que se custodian en la National Gallery, el de 1606 que se localiza en la Akademie der bildenden Künste de Viena y otros dos en el Museo del Prado que se realizaron hacia los años 1606 y 1638.

Vamos a detenernos en esta última pintura que el cardenal-infante encargó para el rey Felipe IV y que desde el año 1653 se encontraba en el Palacio del Buen Retiro [Fig. 1]. ${ }^{2}$

1. GonzÁlez de Zárate J. M.: «Mitos en metáforas. De algunas pinturas en el Museo del Prado». En vv. AA.: Los Dioses Cautivos., Museo del Prado.

2. Se señala en el catálogo: Realizado por Rubens en su última etapa, toma a su segunda esposa Helène Fourment como modelo para la diosa Venus. Se ha supuesto que la realización del paisaje se deba a la colaboración de Lucas van Uden. Fue encargado por el cardenal-infante para Felipe IV. En 1653 ya estaba en las salas del Palacio del Buen Retiro. 


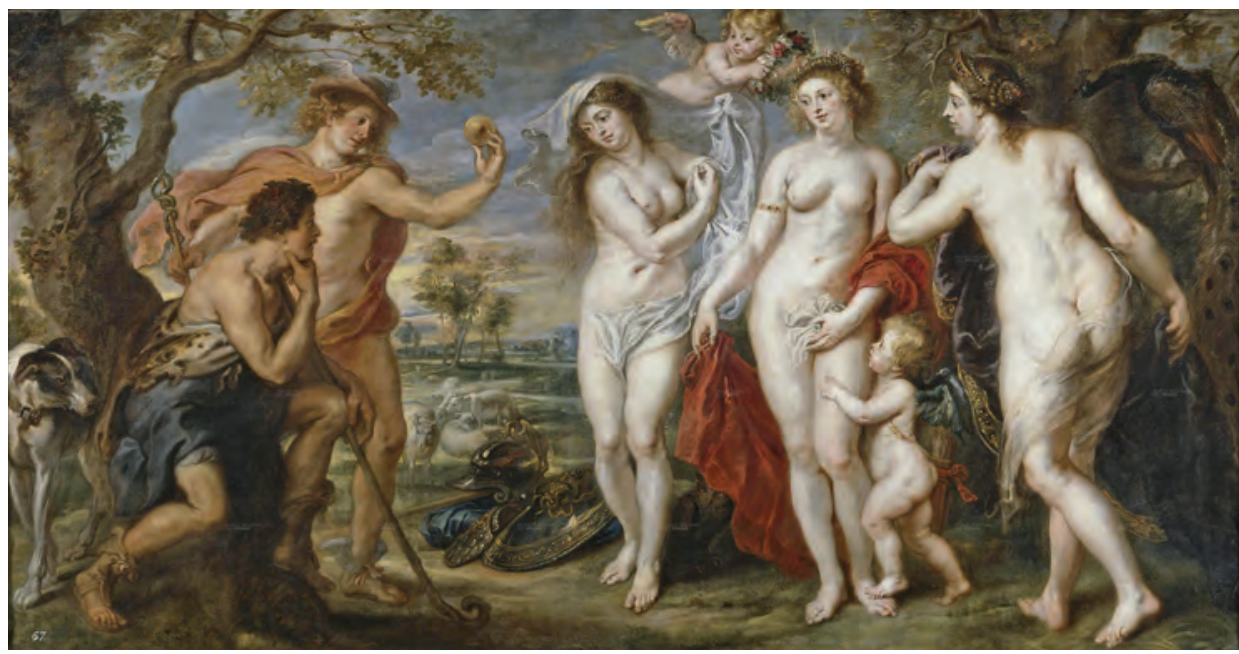

Fig. 1. Rubens, Juicio de Paris, Museo del Prado

La leyenda sobre este afamado juicio, por todos conocido, nos habla del descenso de Mercurio del Olimpo para llevar a Paris la manzana de oro que la Discordia presentó en las bodas de Tetis y Peleo. La manzana establecía que debería entregarse a la diosa más bella y, por consejo de Mercurio, el dios Júpiter determinó que la elección la realizara Paris, hijo de Príamo, rey de Troya, quien residía -ignorando su origen- como pastor en el monte Ida. Así lo cuenta Homero en la Ilíada donde repara en Paris, a quien denomina Alejandro:

De tal manera Aquiles, enojado, insultaba al divino Héctor. Al contemplarlo, compadecíanse los bienaventurados dioses a instigaban al vigilante Argicida a que hurtase el cadáver. A todos les gustaba tal propósito, menos a Hera, a Posidón y a la virgen de ojos de lechuza, que odiaban como antes a la sagrada Ilio, a Príamo y a su pueblo por la injuria que Alejandro había inferido a las diosas cuando fueron a su cabaña y declaró vencedora a la que le había ofrecido funesta liviandad (XXIV, 25-30).

También encontramos el relato en Ciprias (fragmentos), Ovidio (Heroidas XVI,71ff, 149-152 y v.35f), Luciano (Diálogo de los dioses, 20), Higinio (Fábulas 92) y Eurípides (Andrómaca, 284; Helena, 676). Pausanias en el siglo II y en su Descripción de Grecia así lo relata:

Mercurio llevando a Paris, el hijo de Príamo, las diosas cuya belleza ha de juzgar, siendo la inscripción sobre ellos: «Aquí está Hermes, quien indica a Alejandro que debe decidir sobre la belleza de Hera, Atenea y Afrodita» (V. 19,5). 


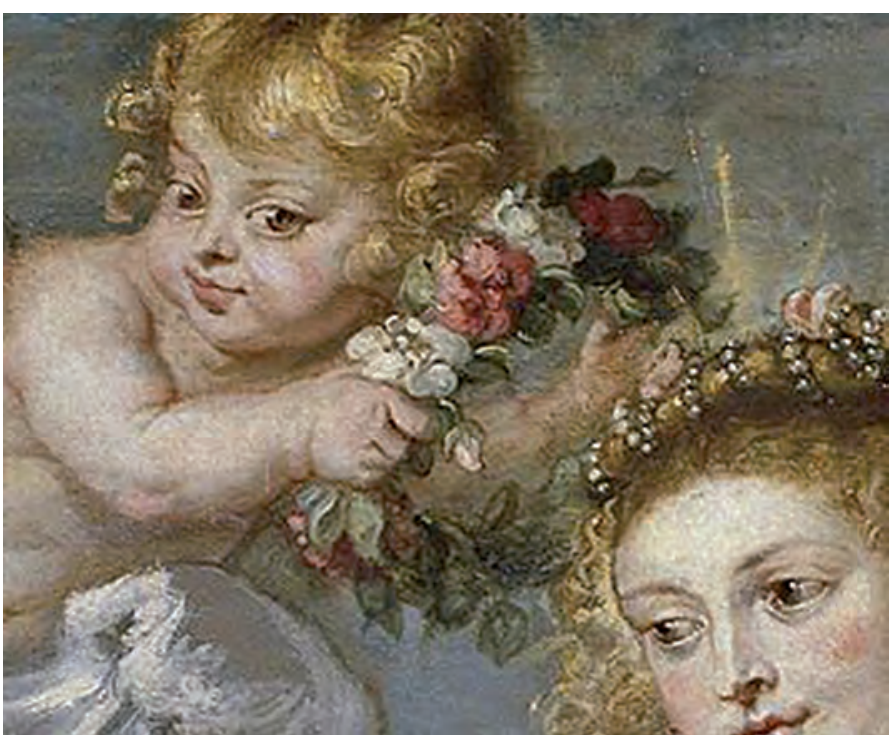

Fig. 2. Juicio de Paris (detalle)

En el concurso Juno, Atenea y Venus son obligadas a desvestirse por Paris para poder efectuar su elección. Ellas ofrecen sus presentes al regio juez: la primera el dominio de los Estados, la segunda el conocimiento (no las armas) y la tercera, a la mujer más bella en el mundo conocido: Helena, esposa del griego Menelao. Los atributos definen con claridad el bello concurso olímpico y, por el pavo real, reconocemos a Hera-Juno; por el escudo, armadura y lechuza a Atenea-Minerva; finalmente, por el cupido a Afrodita-Venus.

Un encargo del cardenal-infante don Fernando para su hermano, el rey Felipe IV, sin duda tendría un propósito concreto alejado de toda lectura meramente erótica y hedonista. El fin esencial del lienzo, su lectura, plantea desde el imaginario poético, un sentido político concreto que vamos a comentar.

La diosa del Amor y la Belleza destaca en el centro de la composición y se nos presenta en el momento concreto, cuando un cupido, quiere disponer la corona de rosas sobre su cabeza [Fig. 2].

Ripa, en su tratado del siglo XVI, propone la corona de rosas como alegoría del Encanto ya que es la flor de Venus. En su comentario sobre este asunto, el Juicio de Paris, nos dice que tanto Minerva como Juno se coronaron con las citadas flores y se vieron bellas, pero cuando descansó en la cabeza de Venus quedaron asombradas de tanta hermosura, añade: ${ }^{3}$

3. Cesare Ripa publicó su Iconologia en Roma en el año 1593. La obra recoge un conjunto de alegorías que a partir de esa fecha fueron muy seguidas como un auténtico diccionario o enciclopedia por artistas, poetas y la intelectualidad en general. A partir del siglo XVII fue muy ilustrada siendo la primera edición que se acompañó de imágenes en 1603. 
[...] la rosa, por el encanto que posee, es reina de las flores, adorno de la tierra, esplendor de las plantas y florido ojo que inspira amor y concilia las delicias de Venus entre los amantes (Encanto).

Así, la rosa, junto al mirto, se convierte en el tradicional atributo de Venus pues resume la suprema belleza. Los emblemas recogen esta significación como apreciamos en Joaquín Bastus, pues la Empresa XII de Gómez de la Reguera con el mote: Has habet et superat dedicada a la emperatriz Isabel, nos habla de sus desposorios con Carlos V dando cuenta del regalo que el monarca hizo a su esposa. ${ }^{4}$ Nos dice:

Carlos e Isabel vivieron en la unión más perfecta, tratándola siempre con la mayor delicadeza y distinción. Y como efecto de su amor y galantería dio el emperador a la emperatriz las tres gracias por divisa. Con la circunstancia que una de las Gracias llevaba una rosa, otra un ramo de mirto, y la tercera uno de encina con su fruto.

Este bello grupo era un ingenioso Emblema de las especiales dotes que concurrían en la princesa. La rosa simbolizaba la hermosura [...] con un lema que decía: Haec habet, et superat, esto tiene y mucho más.

Con este propósito Basilio Sebastián en su compendio alegórico nos habla de la rosa, moraliza por la flor de Venus, pues nos dice que la figura de la Voluptuosidad, de la Delicia o el Placer se ha de representar mediante: ${ }^{5}$

[...] una joven hermosa acostada en un lecho de mirto y de rosas, de mirar lánguido, invitando a las caricias del amor, pero su tez pálida anuncia que la tristeza sigue paso a paso a los placeres.

El citado atributo de Venus, imagen de la Belleza y el Amor, tiene su expresión en la Antigüedad clásica. A modo de ejemplo podemos reparar en el texto Imágenes que Filostrato escribiera en el siglo III. El tratadista, considerando el amor entre Baco y Ariadna, nos dice:

[...] aquí, Dionisio solo está representado por su amor [...]. Dioniso se ha echado encima un manto de púrpura y ha puesto rosas en su cabellos para acercarse a Ariadna, ebrio de amor, como dice el poeta de Teos de quienes han sido vencidos por la pasión amorosa $(\mathrm{I}, 15)$.

Conti, en su Mitología, siguiendo el poema que Nicandro escribiera en el siglo il a. C., nos cuenta que la diosa acudió al señalado juicio con la citada corona: «Además de estos, Dictina odió tus ramas y Hera, la de Imbros, solamente no acepta la corona, a causa de que, cuando los inmortales se exaltaron para el certamen de la belleza, adornaban a Cipris en el monte Ida" (Mitología. Edición consultada Murcia 1988, p. 293).

4. Gómez de la Reguera, F.: Empresas de los Reyes de Castilla y de León, 1632, Empresa XXIII. Bastus, J.: El Trivio y El Cuadrivio o la Nueva Enciclopedia., Barcelona, 1862, p. 92.

5. Sebastián, B.: Compendio del sistema alegórico, y diccionario manual de la iconología, Madrid, 1850, p. 256. 
Esta lectura, como es sabido, fue muy general y para nada extraña contemplar la flor acompañando a Venus, las pinturas de Tiziano son claro ejemplo que se extiende en el tiempo. Así, Fabré, en su descripción del Placer comentando una de las pinturas de Vicente López para el Palacio Real, nos dice: ${ }^{6}$

El Placer se ve simbolizado por un gallardo mancebo, en cuyo rostro y cuerpo se hallan cifradas la hermosura y gracia: la guirnalda de mirto y las rosas que ciñen sus sienes, y la cítara de oro que tañen también sus bien formadas manos, manifiestan su carácter.

Se manifiesta con claridad la idea de Venus como triunfadora en el concurso olímpico de la belleza, pero la idea, el propósito del artista en este argumento que vamos considerando tiene, seguramente, otra lectura que vamos a comentar.

Edgar Wind, como propone el emblemista Sambucus en el siglo XVI, analiza el sentido de esta composición que supera la mera lectura literal. Por las tres diosas se manifiestan tres comportamientos de vida: Juno-vida activa, Ateneavida contemplativa y Venus-vida sensual.

La aplicación señalada queda referida en el mitógrafo Conti y en su Mitologia editada en Venecia en 1567, donde lo explica con claridad al relacionar la idea de gobierno con el resultado de tan infortunado juicio:

Así pues los antiguos, para impulsar con fuerza a los hombres que tenían que reinar hacia las dotes de mando, inventaron esta fábula, mediante la cual dijeron que convenía que fuera moderado, sabio y con fortuna aquel que tenía que gobernar a los restantes hombres, puesto que Paris, tras despreciar la sabiduría y las riquezas por su lujuria perdió el imperio. Pues cuando recrea más en una afición, se dice que esa apetencia del ánimo es Paris. A este le fueron concedidas aquellas diosas para que las juzgara y todas parecían dignas de vencer, aunque Juno prometía el reino (vida activa), Palas la sabiduría (vida contemplativa), Venus la mujer más hermosa (vida sensual) para obtener la victoria en aquel certamen. Pero, ¿quién en su sano juicio va a elegir en lugar del poder, las magistraturas y los honores a la más vergonzosa cortesana?

El mitógrafo sentencia tras su narración y nos ofrece el sentido de la misma aplicado al mal gobernante arrastrado por los placeres: ${ }^{7}$

No hay ninguno de nosotros, gracias a los dioses inmortales, que no condene a Paris por su juicio, pero tampoco hay casi nadie que no imite el vergonzoso juicio de Paris. Exponiendo esta acción vergonzosa de Paris, los antiguos hicieron que nosotros condenáramos nuestra propia locura, pues Venus, a la

6. AвRÉ, F. J.: Descripción de las alegorías pintadas en las bóvedas del Real Palacio, Madrid, 1829, p. 226.

7. Conti, N.: Mythologiae sive explicationis fabularum libri decem, in quibus omnia prope Naturalis E Moralis Philosophiae dogmata contenta fuisse demonstatur, Venecia, 1567, Edición consultada Murcia 1988, p. 475. 
que Paris consideró en tanto, no es otra cosa que la locura, como su propio nombre significa [...].

Sin duda, la fuente de Conti la encontramos en el Mitologiarum Libri III que escribiera Fulgencio en el siglo vi donde establece una clara interpretación alegórica de este argumento siguiendo el tradicional sentido doctrinal. Considera siguiendo a Platón-(Rep. IX, 7. Precisa que se divide en tres el alma de cada individuo) y Aristóteles (Etic. X, VIII. Propone la vida contemplativa sobre la activa) - que el alma humana dispone de tres modos de vida entre los que se puede optar: la vida contemplativa referida por Atenea-Minerva; la activa figurada por Hera-Juno y la sensual a la que remite Afrodita-Venus (Fulgencio. L.II,I Fabula de iudicio Paridis). Tanto en Fulgencio, como en Conti, por Paris, Alejandro, se debe entender al mal hombre que toma, entre los tres comportamientos, el placer. ${ }^{8}$ Este es el sentido que observamos en el fresco del siglo Xv conservado en el castillo Monselice de Venecia donde Juno queda vestida a modo de guerrera como elemento activo, Minerva porta el libro y la desnudez de Venus figura su claro sentido que vamos comentando [Fig. 3].

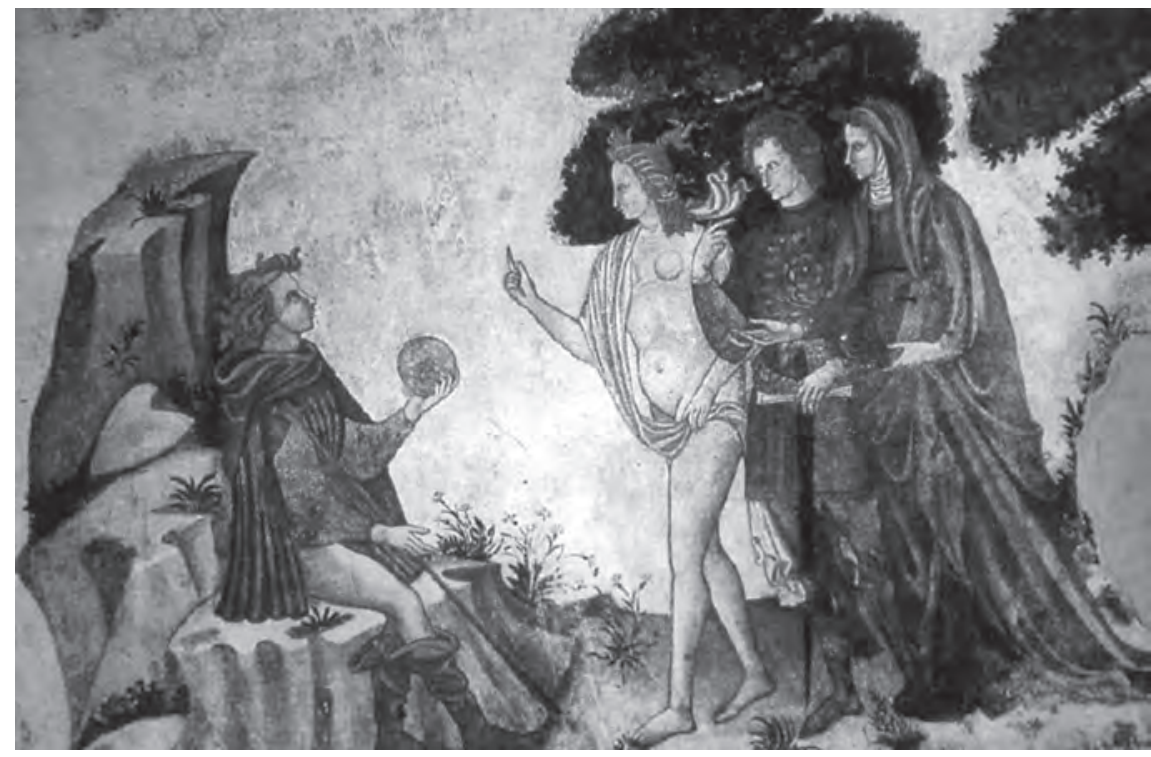

Fig. 3. Juicio de Paris, Castillo de Monselice, Venecia, siglo xv

8. Paris, denominado también Alejandro cuyo significado es «quien aleja del peligro» debido a que fue rescatado por pastores y encargado desde su infancia de cuidar que los rebaños no fueran robados. Guido delle Colonne considera que Júpiter le cambió el nombre por lo acertado de sus juicios y por ello le nominó como Paris en Colonne G.: La Crónica Troyana, en que se contiene la total y lamentable destrucción de la nombrada Troya., Toledo, 1562, l. III, cap. III. 


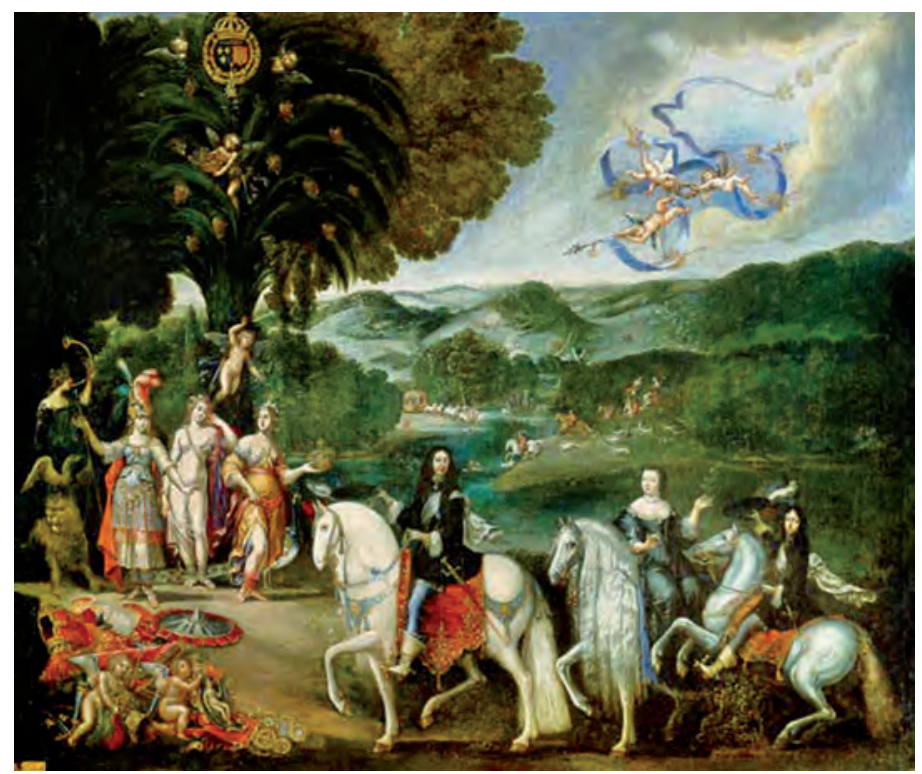

Fig. 4. Anónimo, Alegoría del matrimonio de Luis XIV, Versalles, siglo XVII

Sabido es el resultado de la elección de Paris, imagen, en este caso, de quien tiene la responsabilidad del poder. Paris, se convierte en figura del mal gobernante pues tomó como premio a Helena y con ella llegó el desastre a Troya, su destrucción. En este sentido el texto de Conti explica suficientemente la pintura anónima del siglo XVII sobre la Alegoría del matrimonio de Luis XIV conservada en Versalles [Fig. 4]. En ella, se representan las tres diosas retadas en el Juicio de Paris; el monarca, acompañado de su esposa María Teresa, parece ignorar a Venus a sabiendas de las verdaderas funciones del poder. Así, el Juicio de Paris se convierte en algo más que una mera fábula, responde a una clara alegoría de un mal gobierno de fundamentarse solamente en los placeres mundanos.

En este caso la pintura, muy probablemente, quiera a su vez remitir a que las tres ofertas: Belleza, Poder y Sabiduría, se resumen en la reina María Teresa. ${ }^{9}$

Sabida es la creencia medieval según la cual las casas reales de Europa provienen de Troya. En este sentido surgió la leyenda de Paris dormido, es decir, el Sueño de Paris donde, dormido el pastor regio acaeció el mencionado Juicio justificando, en consecuencia, la sensual e incomoda elección. Todo fue un sueño, un onírico aviso para gobernantes.

La fuente literaria es antigua y proviene de Dares el Frigio quien en el siglo I escribiera su De excidio Troiae, escrito que influyó en el siglo XII en Benoît de

9. Al fondo de la composición podemos observar el río Bidasoa y la isla de los Faisanes donde se dispone una real carroza. Se precisa con ello la llegada de María Teresa para desposarse con Luis XIV en San Juan de Luz en el año 1660. 


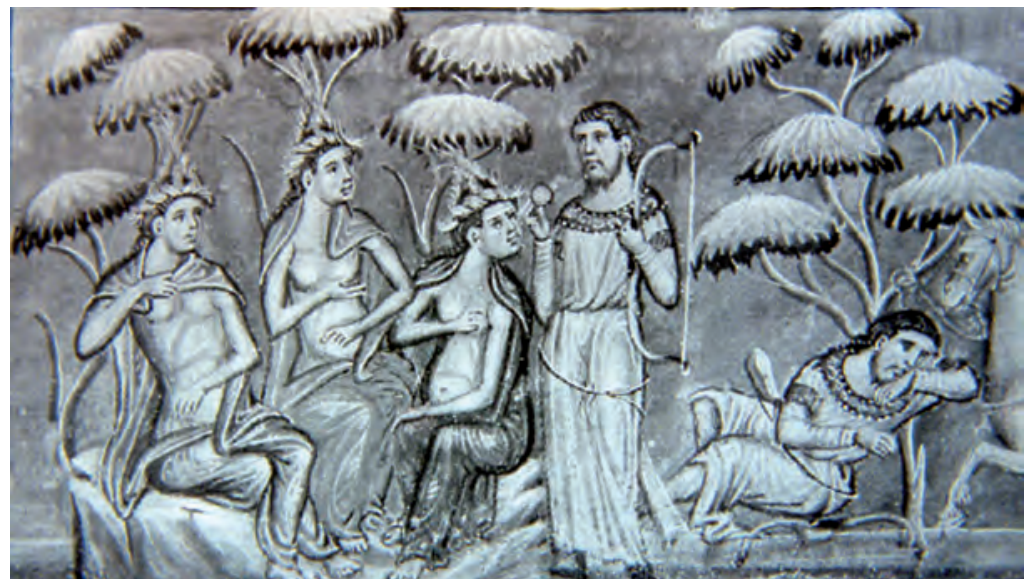

Fig. 5. Sueño de Paris, Historia de la destrucción de Troya, siglo XIV

Sainte-Maure y su Roman de Troie. La exposición de Dares se continuó de igual manera por Guido delle Colonne quien compuso en el siglo xiII su Historia de la destrucción de Troya (traducido al castellano por Pedro López de Ayala), en alguna de sus ediciones ilustradas del siglo xIv se presenta con claridad este asunto del llamado Sueño de Paris [Fig. 5]..$^{10}$ Nos cuenta que Paris, perdido cuando cazaba, se durmió tras atar su caballo en el árbol; en este tiempo se le apareció Mercurio en su sueño junto a las tres diosas.

El escrito de Dares fue muy considerado en la Edad Media donde circuló a través de diferentes manuscritos, también en la Moderna. Es en este tiempo que, a imitación de Roma, las naciones quisieron encontrar su origen en Troya y, más concretamente, en la descendencia de Príamo. Así, en el siglo viı Deacon consideraba a Carlomagno descendiente de Anquises, y como nos cuenta la historiadora Tanner:

[...] a mediados del siglo viI la crónica de Frederagius reclamaba la descendencia troyana de los merovingios siguiendo a Dares; los sajones heredan esta descendencia con la coronación en el año 926 en San Pedro de Roma de Otto I, ligado a la dinastía corolingia y merovingia por su matrimonio con Adelaida de Borgoña; la dinastía de los Habsburgo también reclamaba su descendencia troyana desde su primer emperador, Rodolfo I, a finales del siglo XIII.

10. La obra de Guido delle Colonne fue editada en castellano. Tenemos la de 1552 y 1562 en Toledo. En el siglo XVIII Jacob Perizonius analizó los escritos de Dares y concluyó que eran apócrifos. TANner, M.: The last descendant of Aeneas: the Hapsburgs and the mythic image of the emperor, New Haven, 1993. Sobre la descendencia de Troya por parte de las monarquías europeas: DAmisch, H.: El Juicio de Paris. Iconología Analítica, México D. F., 1996. Recoge la siguiente bibliografía en su estudio: Respecto al sueño de Paris: Förster, R.: «Neue Cranachs in Schliesen», en Schliesens Vorzeil in Bild und Schrift, VII (1898), p. 269. Los argumentos de Cranach sobre el Juicio de Paris: Friedläender, M. J. y Rosenberg, J.: Les peintres de Lucas Cranach, París, 1978, cat. 41, p. 79 


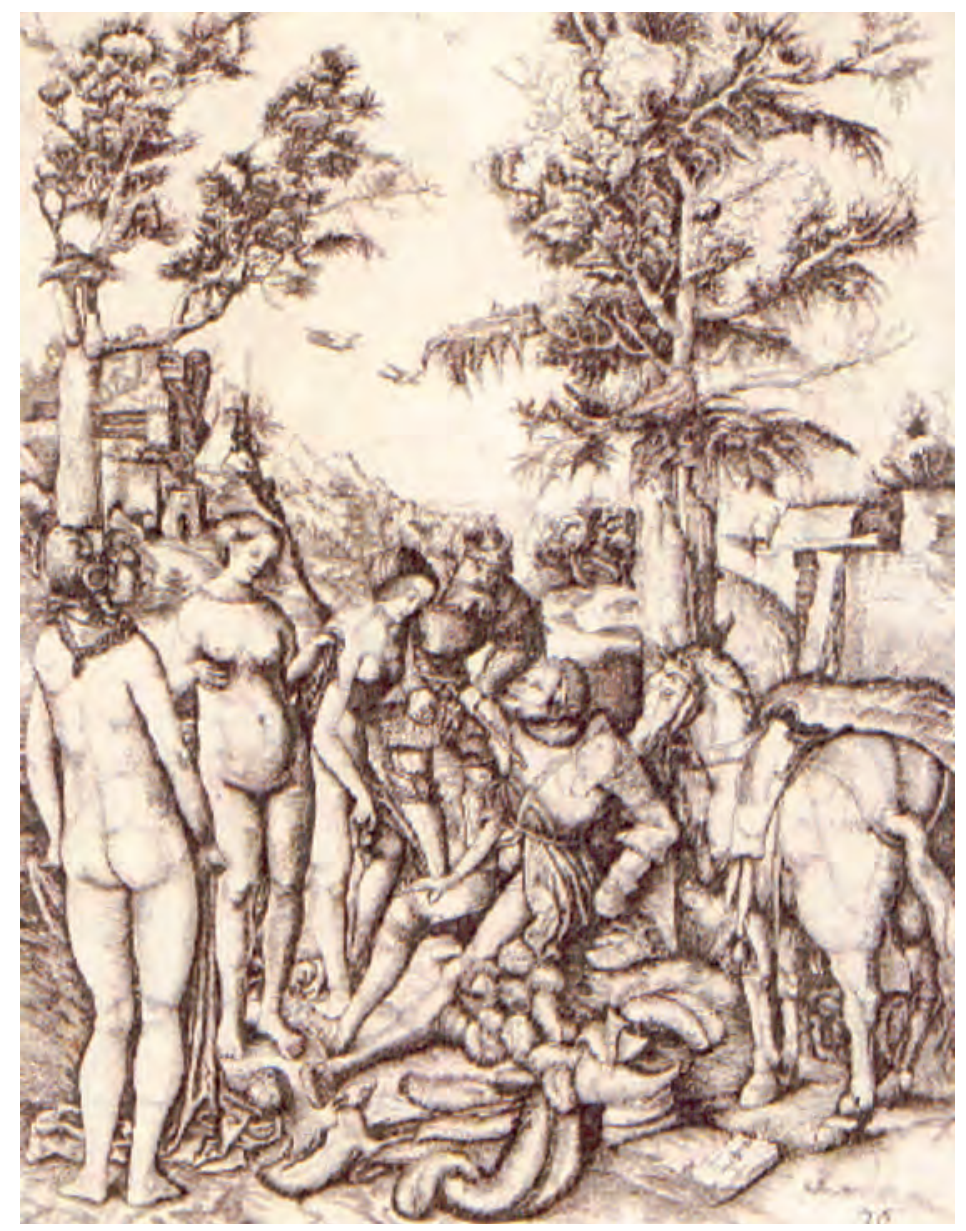

Fig. 6. LuCAs Cranach, Sueño de Paris

Y así lo consideró el tiempo del llamado Renacimiento ya que juzgó a los francos y al propio emperador Maximiliano como descendientes del hijo de Héctor, Francus.

El arte no se mantuvo ajeno a la literatura y son varios los artistas que recogen el argumento del Juicio de Paris como el Sueño de Paris, así lo vemos en varias composiciones del siglo XVI como en las pinturas de Cranach y en sus estampas, que ya analizaron Friedläender y Rosenberg [Fig. 6]. También en invención de Durero grabada por Hopfer [Fig. 7] y en la pintura conservada en el Museo del Louvre que realizara Pieter van Coecke [Fig. 8]. 


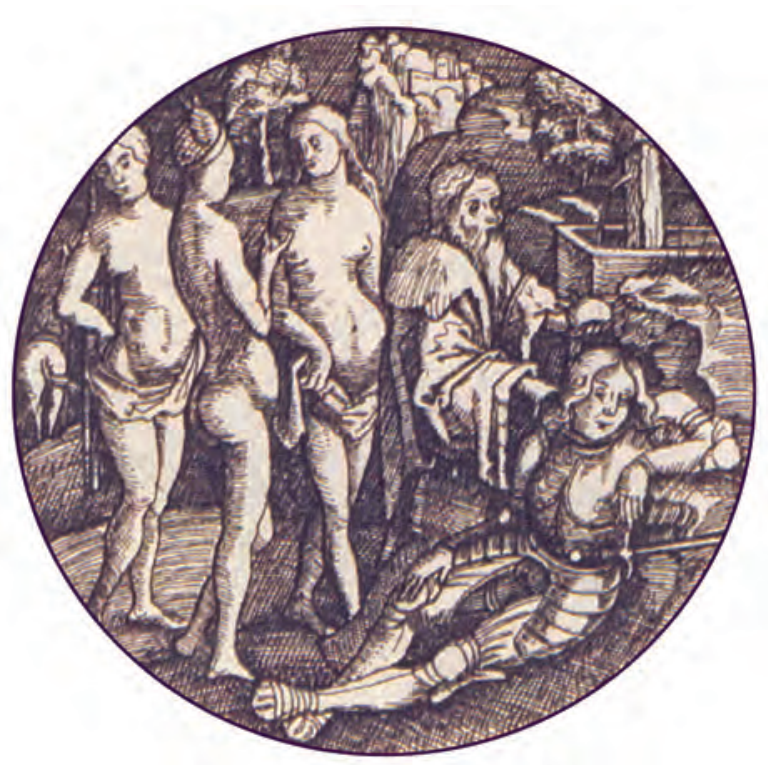

Fig. 7. Invención de Alberto Durero en estampa de Hopfer, Sueño de Paris

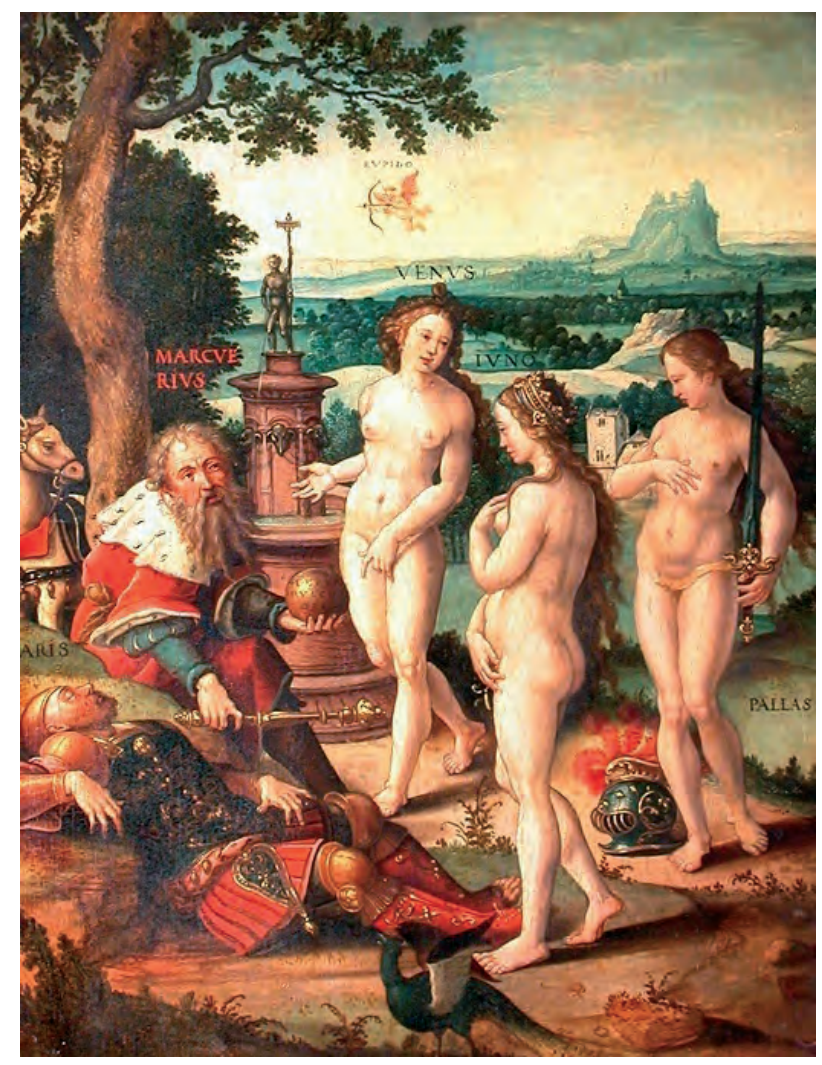

Fig. 8. Pieter van Coecke, Sueño de Paris, Museo del Louvre 
La literatura visual y semántica, términos en los que definimos la Emblemática, recoge en el sentido que analizamos el argumento sobre el Juicio de Paris, es decir, una referencia al mal gobierno tanto en el comportamiento personal como en el político.

Paolo Maccio propone esta composición en sus emblemas para decirnos que el mal juez se hace daño a sí mismo [Fig. 9]. ${ }^{11}$ Esta es la consecuencia de un amor desviado a lo meramente sensual, pues quien toma la elección del mero placer hedónico a sí mismo se daña. Hernando de Soto propone el Juicio de Paris como cuerpo de su emblema para decirnos que todo lo vence el amor ya que la lujuria trastorna el juicio en el ser humano [Fig. 10]. ${ }^{12}$ Por ello no extraña que Daniel La Feuille ocupe su Emblema 729 con este argumento y por el Juicio de Paris quiera entender y proponga en su lema a quien: Es ciego en su escogimiento [Fig. 11] ${ }^{13}$ El emblemista Bartholomey Aneau dispone este cuerpo del emblema para significar el mal juicio guiado por la voluptuosidad [Fig. 12].$^{14}$ El precedente lo encontramos en la citada edición de Sambucus donde observamos el conocido argumento con similar sentido [Fig. 13]. ${ }^{15}$

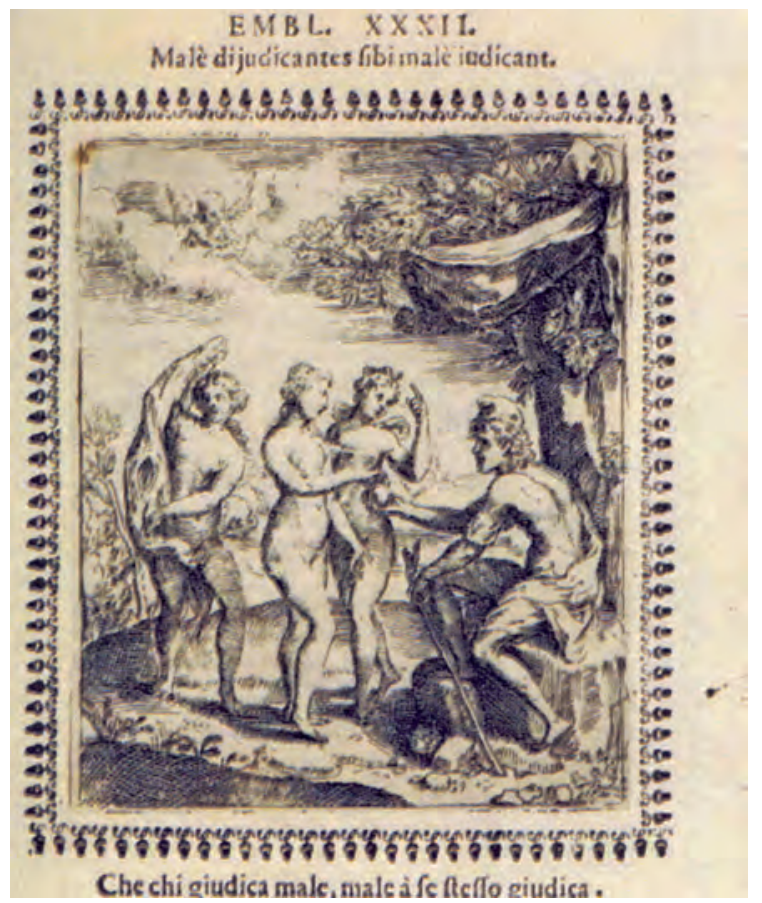

Fig. 9. Emblema de Paolo Maccio, Juicio de Paris. Emblema XXXII (1628)

11. MACCIO, P.: Emblemata, Bolonia, 1628. El emblema XXXII con el mote: Che chi giudica male, male à se stesso giudica.

12. Sото, H.: Emblemas Moralizada, Madrid, 1599. Emblema XVIII.

13. La Feuille, D.: Symbola et Emblemata, p. 244. Emblema 729.

14. ANEAU, B.: Imaginación poétique,,Edición 1552, p. 87

15. Sambucus, J.: Emblemata, Amberes, 1566. Emblema p. 131 con el mote: Iudicium Paridis. 


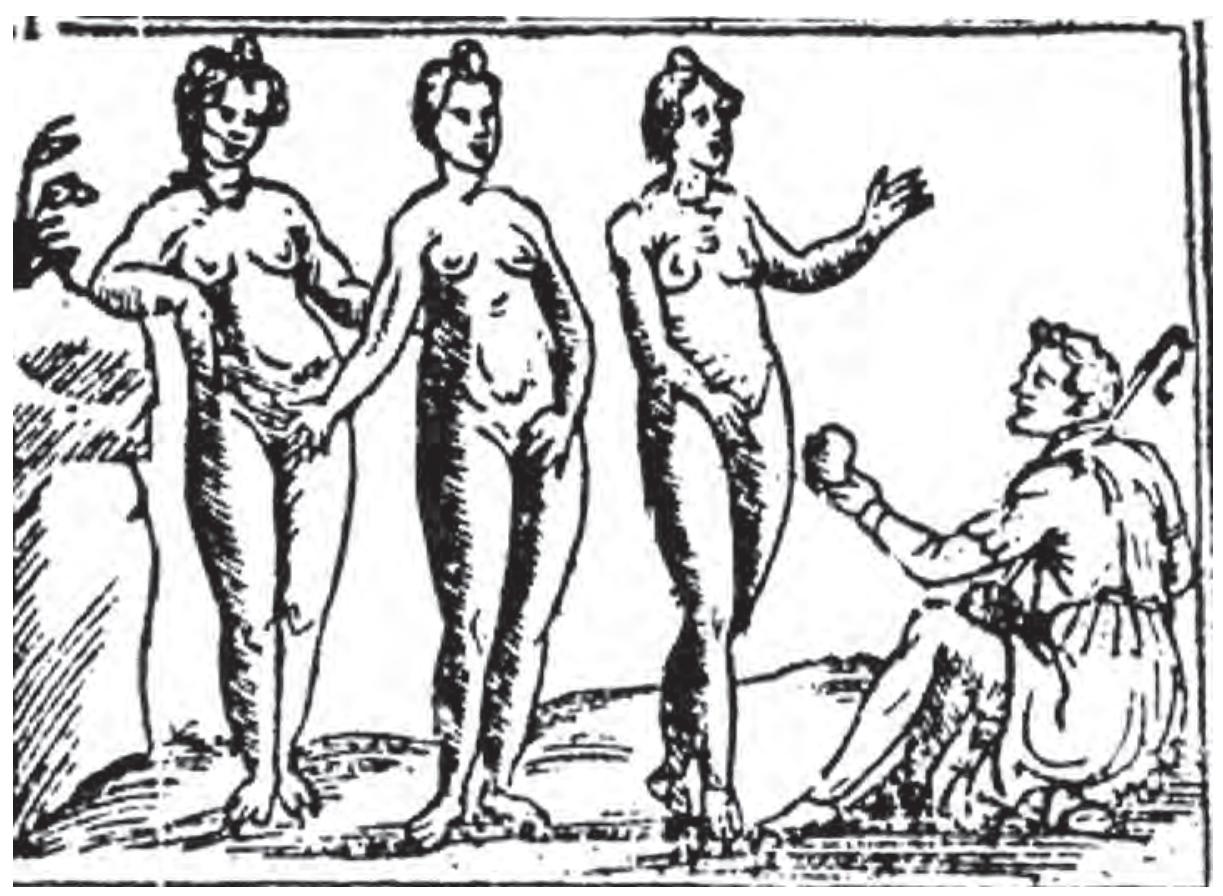

Fig. 10. Emblema de Hernando DE Soto, Juicio de Paris. Emblema XVIII (1599)

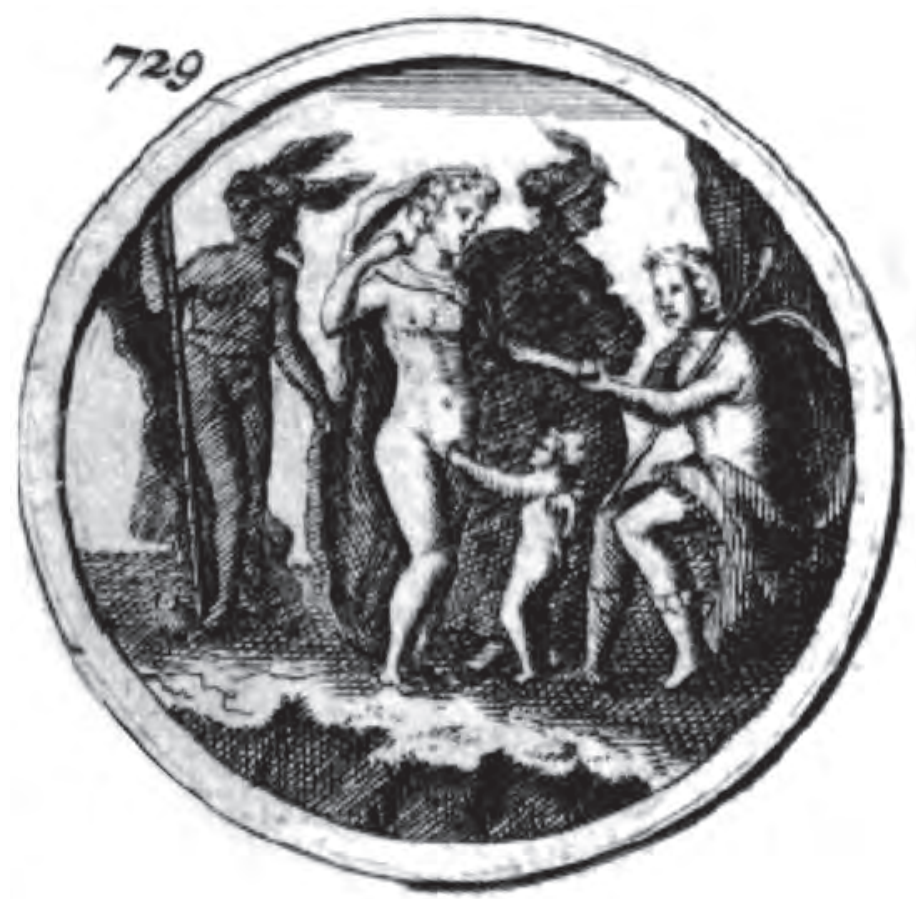

Fig. 11. Emblema de Daniel La Feuille, Juicio de Paris. Emblema 729. (1700) 


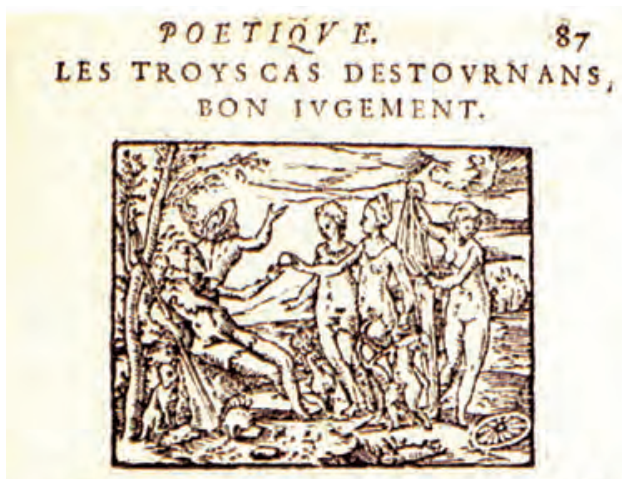

$G_{R A N D E}$ Richeffe, Ignorar:ce des chofes, Teuneffe folle aufsi:à veuës clofes

Des fens deceuz,aueuglent les eff'ritz

Tant que l'honneur honnelte eft en defpris:

Vertu aufsi.Mais belle Volupté

Seulle eft, qui plaict au fol fens delecté.

TESMO1 N l'Arreft que Paris profera.

Quand à Iunon,\& Pallas prẹfera

Dame Venus.Comme eftant filz de Roy,

Ruftic.\& Ieune. A vant lestrois en foy.

Fig. 12. Emblema de Bartholomey Aneau, Juicio de Paris (1552)

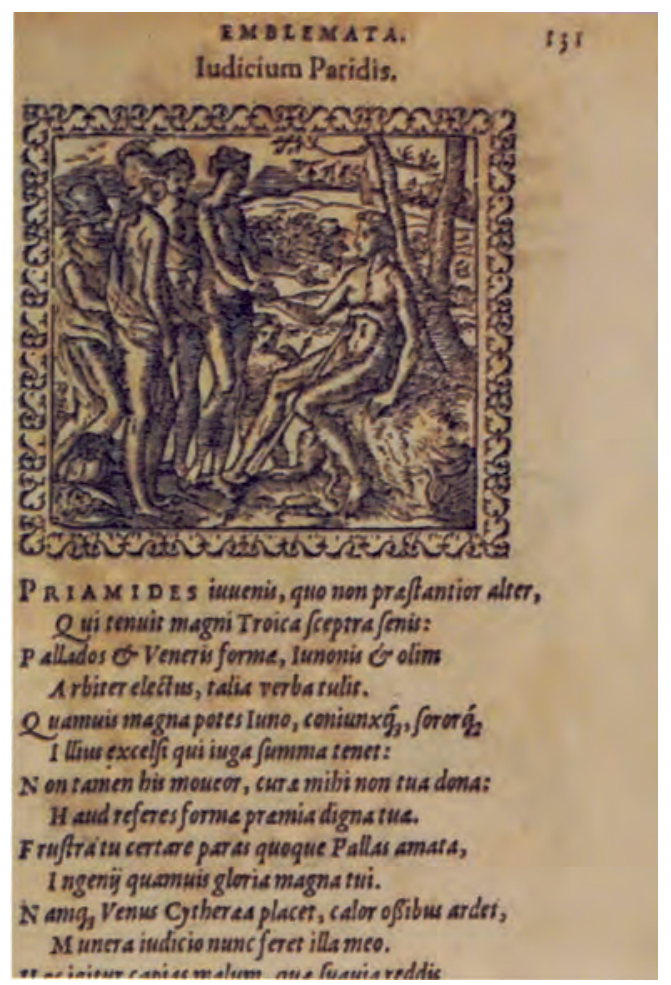

Fig. 13. Emblema de SAmbucus, Juicio de Paris (1556) 
Los ejemplos son claros y conformes a la idea del mal juicio de la razón al someterse a los placeres. Y en este aspecto radica la intencionalidad del argumento en Rubens quien, entre otros singulares artistas, destacó por el uso en sus pinturas de la metáfora, del «otro hablar» que comentamos al inicio de esta exposición.

Sabida es la relación que el artista flamenco tuvo con miembros de la llamada «familia caritatis», grupo destacado en el humanismo flamenco con una clara orientación cristiana senequista de la que ya dimos cuenta en otro de nuestros trabajos ${ }^{16}$ y estudió Max Rooses. ${ }^{17}$ Su pintura conocida como Los cuatro filósofos realizada entre 1611-12 y conservada en la Galería Pitti [Fig. 14.] de Florencia, pone de manifiesto esta relación y su orientación hacia estas ideas propias del estoicismo tan vivo en la Flandes del siglo XVI y XVII. En la citada pintura observamos al propio artista junto a su hermano, el filósofo Felipe Rubens, también a Johannes Woverius y al maestro de todos, Justus Lipsius. Ellos se presentan junto al busto de Séneca como manifestación de las ideas subyacentes en sus pensamientos claramente provenientes de la filosofía y del pensamiento ya señalado, el estoicismo.

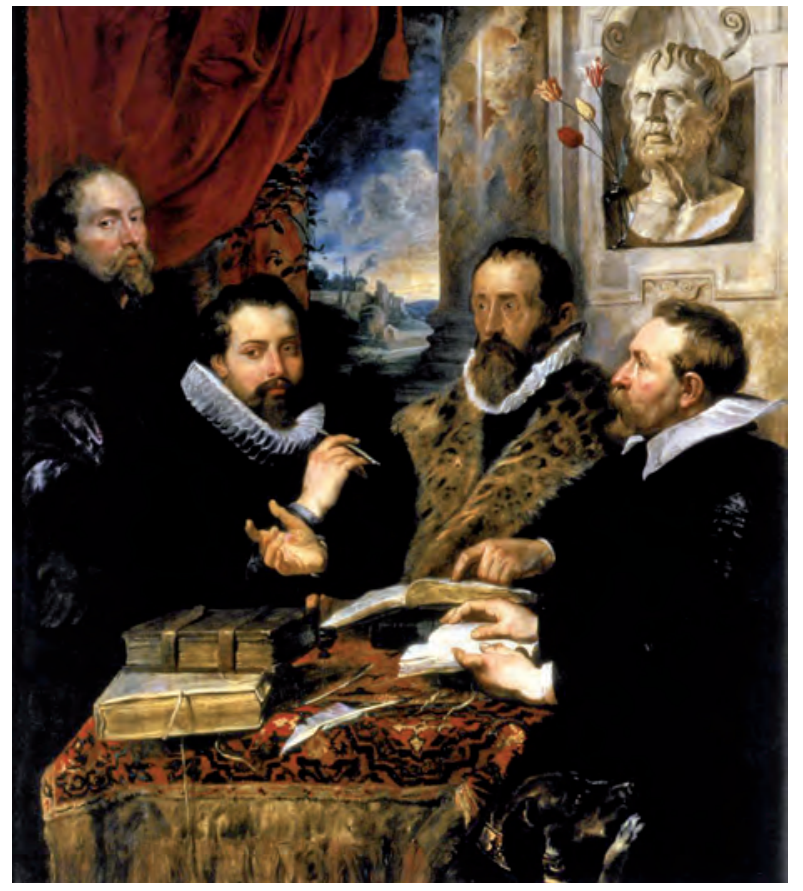

Fig. 14. Rubens, Los cuatro filósofos, Galería Pitti

16. González de Zárate J. M.: El Génesis y su entorno. Imágenes de Peter van der Borcht en el contexto de la «Familia Charitatis», (Catálogo de la exposición celebrada en Vitoria, Sala. NH, del 21 de abril al 5 de mayo de 1993; Madrid, Fundación Carlos de Amberes, del 15 de septiembre al 15 de octubre de 1993; Murcia, Centro de Arte Palacio Almudí, del 14 de diciembre de 1994 al 14 de enero de 1995), Vitoria, Instituto Ephialte, 1993.

17. Rooses, M. : L'Oeuvre de P. P. Rubens, Amberes, 1886. 
Por otra parte la figura de Otto van Vaen, Otho Vaenius, debemos considerarla en relación con nuestro comentario. Destacó como singular pintor y además por sus reconocidos libros de emblemas, sin olvidar que fue uno de los primeros maestros de Rubens entre los años 1595 y 1598 . Su formación humanista y clásica sin duda dejó huella en el maestro de Amberes.

Horatii Flacci Emblemata editado en Amberes en 1612 fue quizá la obra de Vaenius que gozó de una notable divulgación en Europa. La edición castellana fue conocida con el título Teatro moral de la vida humana. La obra de Vaenius se publicó en diferentes idiomas tanto en el siglo XVII como en la siguiente centuria. Curiosamente, varias de estas ediciones se acompañaban de la Tabla de Cebes o discurso del hombre desde su nacimiento hasta templo de la virtud (su meta final) y, del Enchyridion de Epicteto, es decir, de la filosofía estoica de la cual la obra de Vaenius estaba sumamente informada. Esta inclusión la apreciamos en la edición del año 1669 que publicara el tipógrafo Foppens en Amberes.

El sentido de la filosofía estoica que manifiesta Epicteto, pensador del siglo I, es manifiesto en el tratado y pensamiento de Vaenius, aspecto que no debe extrañar por cuanto el Manual del filósofo romano fue muy editado en el siglo XVI. Los presupuestos estoicos sobre la fortaleza de ánimo, el sufrir con paciencia las desventuras, dominar las pasiones sometiéndolas a la razón, quedan claramente expuestos en su epigramas. Al respecto y entre otros ejemplos, Epicteto nos propone a Sócrates como modelo: ${ }^{18}$

Es así como Sócrates alcanzó la perfección, sirviéndose de todas las cosas para su progreso, y no siguiendo sino la razón. Por ti, aun cuando aún no seas como Sócrates, debes vivir como alguien que puede llegar a ser como él.

Por tanto:

[...] la felicidad del hombre se encuentra en una vida virtuosa conforme a la razón, rechazando y renunciando a placeres vanos y voluptuosidades.

\section{En consecuencia:}

Así como al andar te cuidas de pisar un clavo o torcerte un pie, procura también de igual modo no dañar la parte maestra de ti mismo, la razón que te conduce.

Pues como precisa el comentarista de Epicteto en la edición que señalamos se ha de vivir en la eudaimonía, es decir, siempre en conformidad con la razón:

La razón sola es libre en el hombre y la puede llamar propiamente suya; pues no puede ser forzada ni oprimida de algún poder humano: Es un bien interno, en que consiste nuestra felicidad. ${ }^{19}$

18. Eрістето: Enchyrio., Ed. Madrid, 1701, sección LXxiv.

19. Ерістето, secc. II, ensayo II. 
El argumento del Juicio de Paris que Rubens nos presenta, amonesta en este caso al gobernante, le señala que en sus actos de poder debe seguir en todo momento la razón dominando las pasiones y lo voluptuoso y sensual que lo llevan, como al príncipe troyano, al mal gobierno, a la destrucción.

Por tanto, el afamado y poético juicio, tan representado en la Historia del Arte desde los vasos griegos ${ }^{20}$ hasta los grabados de Picasso [Fig. 15] ${ }^{21}$ se convierte en un recuerdo, en una visión onírica de Paris que advierte, a modo de sentencia, la destrucción como consecuencia del mal gobierno. Conti, como señalamos, así lo recordaba al precisar que los antiguos:

[...] inventaron esta fábula, mediante la cual dijeron que convenía que fuera moderado, sabio y con fortuna aquel que tenía que gobernar a los restantes hombres, puesto que Paris, tras despreciar la sabiduría y las riquezas por su lujuria perdió el imperio.

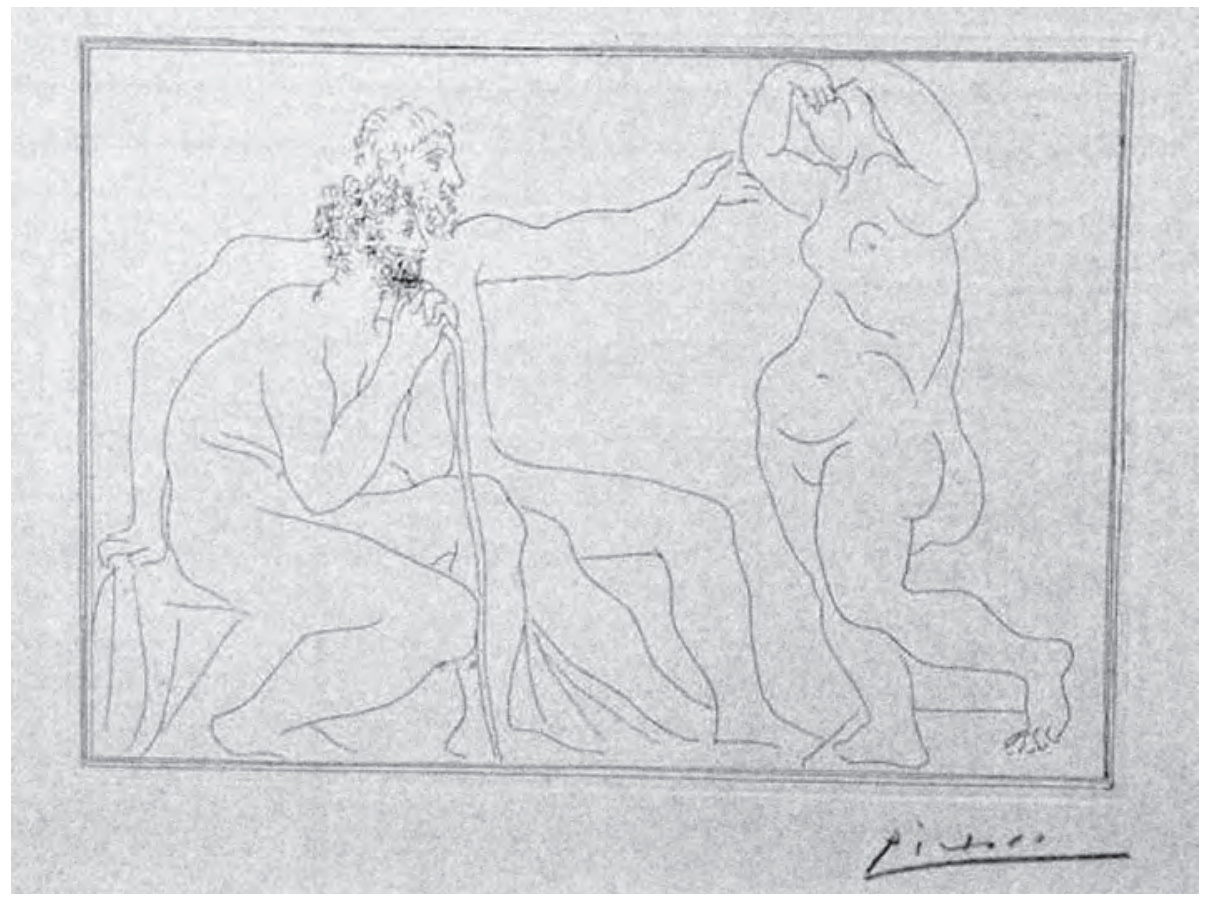

Fig. 15. Dos escultores ante una escultura. PABlo PicAsso, col. La Suite Vollard

20. González de Zárate J. M.: Mitología e Historia del Arte, Vitoria, 1996. Se señalan múltiples ejemplos de esta representación desde los vasos griegos a las estampas y pinturas del siglo XVII.

21. La composición pictórica de Rubens se ha continuado en la historia de las imágenes. Es el caso de Picasso y su Suite Vollard donde la estampa 7 de las 100 que se dan cita en la serie y titulada Dos escultores ante una estatua nos lleva a la pintura de Rubens en el Museo del Prado que hemos comentado. GonZÁLEZ DE ZÁrate J. M.: «La Suite Vollard. El petit coin en la domus aurea de la creatividad picassiana». Publicado en la revista médica Jano (1999). 


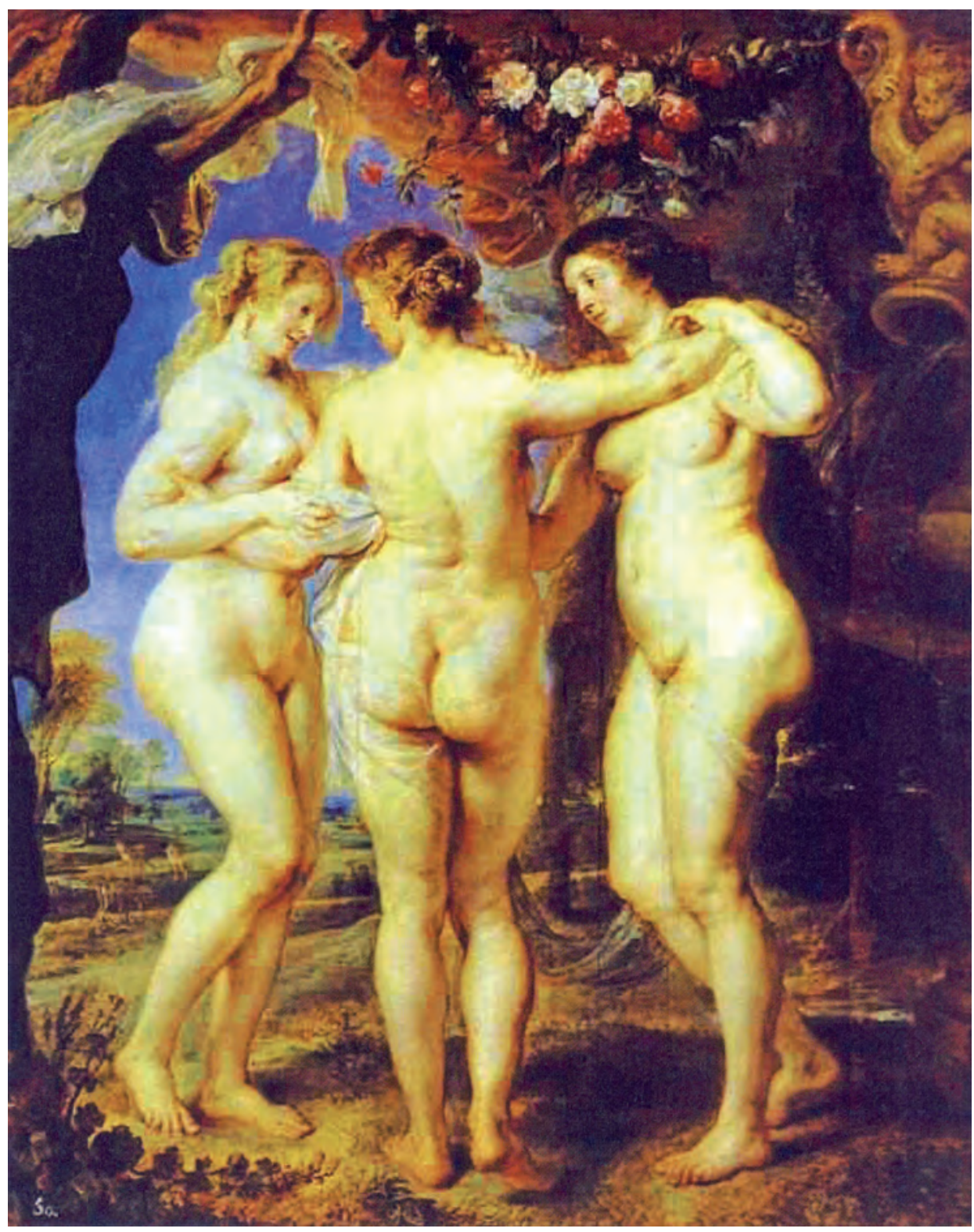

Fig. 16. Rubens, Las Gracias, Museo del Prado

Con esta intención hemos considerado el Juicio de Paris a través de los mitógrafos y la emblemática. Muy bien pudo ser este el propósito esencial del regalo que el cardenal-infante don Fernando, hermano del rey Felipe IV, le hiciera en el año 1638. 
Por la pintura se considera el dominio de la razón, en las acciones de gobierno, donde siempre debe salir vencedora sobre las pasiones mundanas. El sentido final nos lleva al famoso lema atribuido a Epicteto: Sustine et Abstine, soporta y aprende a soportar, sufre y abstente de toda vanidad y voluptuosidad y dirige la vida hacia la virtud porque, en fiando en otras cosas, todo es un sueño que lleva a la perdición. Así se precisa en la Sección LX del Enchyridion en la edición de Madrid en 1733:

[...] en la vida has de tener cuidado, que la parte superior de tu Alma (la razón) no sea ofendida de algunas pasiones brutales, ò de algunas falsas opiniones. Porque saldrás mas fácilmente con tus designios, si observas esta máxima en todas las cosas que emprenderás.

Tras esta enseñanza que se deriva del argumento, no extraña que culminada la pintura, cuando don Fernando la observó, escribiera al rey en este sentido: ${ }^{22}$

\section{[...] las tres diosas están demasiado desnudas.}

Otro de los argumentos muy difundido por la pintura fue el tema de las Tres Gracias, lo apreciamos en Botticelli, Rafael y, entre otros, en Rubens hacia el año 1635 [Fig. 16]. El lienzo permaneció en poder del artista hasta su muerte en 1640, tras esta fecha fue adquirido por Felipe IV y queda documentado en el Alcázar a partir del inventario de $1666 .{ }^{23}$

Las Gracias compusieron, como es sabido, una tríada asociada con Venus que daba a entender la unidad de la diosa explicada por la citada tríada, así lo explica Edgar Wind en sus Misterios paganos del Renacimiento precisando que por ellas los estoicos entendían la liberalidad, mientras que los platónicos consideraban la idea del amor. ${ }^{24}$

En este sentido reparamos en cierto regalo que el emperador Carlos dispuso para su esposa Isabel, donde las Gracias son expresión de las cualidades de Venus: Amor, Hermosura y Fecundidad.

Recordamos que Gómez de la Reguera dedicó su empresa a la emperatriz Isabel con el mote: Has habet et superat [Fig. 17]. ${ }^{25}$ Se trataba de las Gracias que Bastus nos comenta: ${ }^{26}$

Carlos e Isabel vivieron en la unión más perfecta, tratándola siempre con la mayor delicadeza y distinción. Y como efecto de su amor y galantería dio el

22. Cfr. Damisch, Ob. Cit., p. 300. Carta del cardenal-infante Fernando a Felipe IV, 27 de febrero de 1638.

23. En el catálogo del Museo del Prado se señala: «El cuadro permaneció en el Palacio Real hasta que en el siglo XViı entró a formar parte de un grupo de obras en las que los desnudos se consideraron ofensivos y se trasladó a la Real Academia de Bellas Artes de San Fernando. Desde allí se llevó al Prado en 1827».

24. Wind, E.: Misterios paganos del Renacimiento, Barcelona, 1971,p. 45.

25. La fuente procede de: Gómez de la Reguera, F.: Empresas de los Reyes de Castilla y de León, 1632, Empresa XXIII.

26. Bastus, El Trivio y El Cuadrivio, p. 92. 
emperador a la emperatriz las tres gracias por divisa. Con la circunstancia que una de las gracias llevaba una rosa, otra un ramo de mirto, y la tercera uno de encina con su fruto.

Este bello grupo era un ingenioso Emblema de las especiales dotes que concurrían en la princesa. La rosa simbolizaba la hermosura, el arrayán o mirto el amor que tenía por su esposo, y el ramo de encina con su fruto, la fecundidad de la emperatriz; con un lema que decía: Haec habet, et superat, esto tiene y mucho más.

El emblema lo recoge Typotius con el mismo lema presentando a las Gracias [Fig. 18]. ${ }^{27}$ La fuente la podemos encontrar en Pausanias y su Descripción de Grecia cuando describe a las Gracias como compañeras de Venus y nos dice que se acompañaban de una rosa, el mirto y un astrágalo:

[...] un santuario de las Cárites y Xóanas con vestidos dorados, y rostros y manos y pies de mármol blanco. La primera tiene una rosa, la del centro un astrálago y la tercera una rama de mirto. Se puede suponer que tienen lo que he dicho porque la rosa y el mirto están consagrados a Afrodita y están conectados con la leyenda de Adonis, y las Cárites son las diosas que más relacionadas están con Afrodita. El astrálago es un juguete de muchachos y de muchachas que todavía no han perdido los encantos de la edad (VI, 24,7).

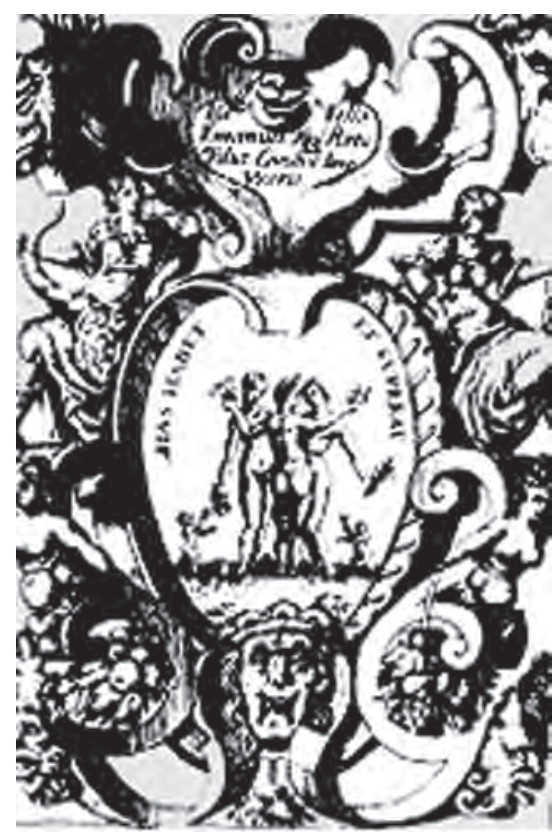

Fig. 17. Emblema de Gómez de la Reguera, Las Gracias. Emblema XXIII (1632)

27. Typotius, J.: Symbola divina et humana, Praga, 1601, parte I. h. XxI. 


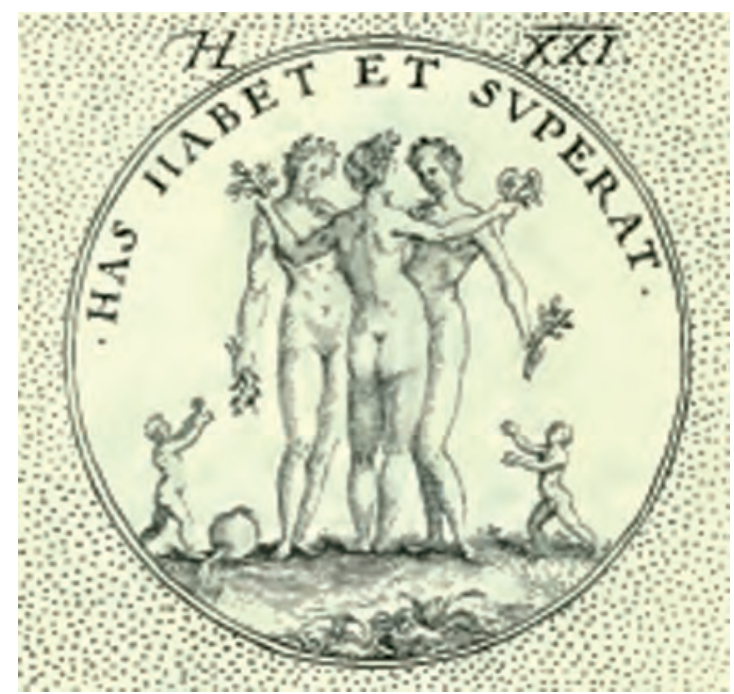

Fig. 18. Emblema de ТүротıUs, Las Gracias. Emblema I. XXI (1601)

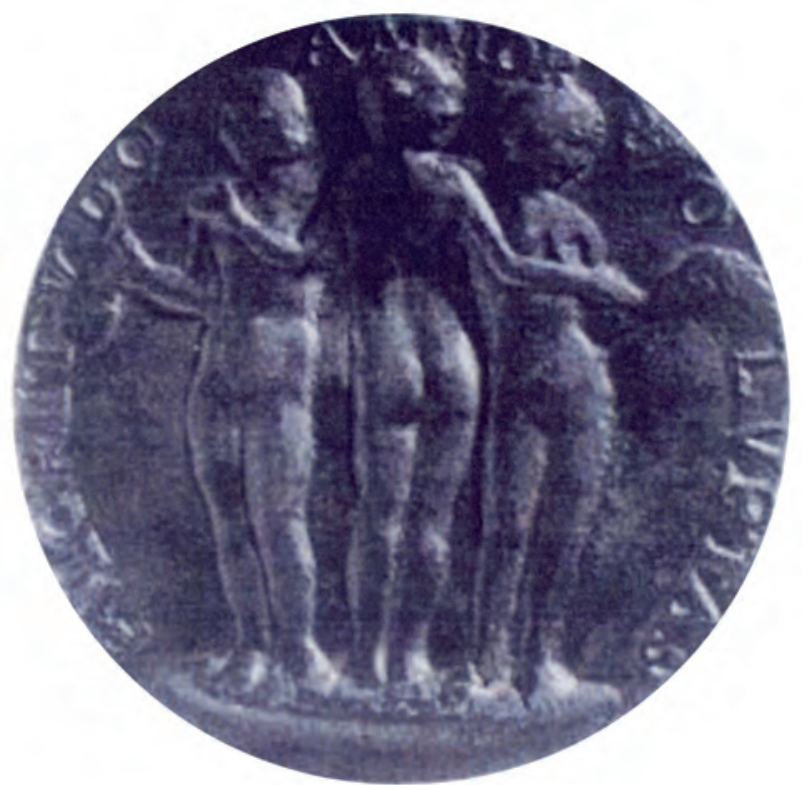

Fig. 19. Medalla de Pico Della Mirandolla, Las Gracias, siglo XV

En relación con el Amor el pensamiento neoplatónico consideró a estas figuras entrelazadas, como observamos en la conocida medalla de Pico della Mirandolla, en referencia a Amor, Voluptas y Pulchritudo, es decir, significando que el Amor no es otra cosa sino un Deseo desesperado por la Belleza [Fig. 19]. 
Por tanto, el Amor es un Gozo, una satisfacción de los sentidos que procura la Belleza. Entendemos así lo que podríamos denominar «línea circular del universo» por la que Dios permite el Amor al hombre para retornar a su punto de partida, es decir, al propio Dios. El filósofo judío del siglo xv, León Hebreo, así lo explica en sus Diálogos de Amor, en edición de Venecia en 1568, donde expresa que Dios creó al hombre con amor para que retorne a la divinidad de igual manera con amor (Dialog. III).

Siguiendo este planteamiento platónico, el mitógrafo Conti precisa que Venus nada hace sin que las Gracias tengan conocimiento: se dice que a esta diosa le fueron dedicadas porque no hace nada sin que ellas lo sepan; pues, cuando se disponía a conseguir de Paris la manzana, dio orden de que fuesen convocados Himeneo, Cupido, los Amores y las Gracias, como dice Pausanias. ${ }^{28}$

Pero no solamente la idea del Amor estaba figurada por las Gracias, también y en un contexto estoico que, como se ha dicho, tanta difusión alcanzó en este tiempo, expresaba la Liberalidad. Fabre resume con claridad estos dos sentidos que denomina alegórico y mitológico. En su comentario a las Tres Gracias que Rafael Mengs pintara en el Palacio Real leemos: ${ }^{29}$

Las Gracias eran hermanas, se llamaban Aglae, Thalía y Eufrosina, y eran compañeras inseparables de Venus. Pueden considerarse bajo dos aspectos, como personajes alegóricos y como mitológicos: como alegóricos presidían a los beneficios y a la gratitud, y por eso son tan bellas y risueñas, porque todo beneficio debe ser dispensado con semblante grato y sinceridad de ánimo. Son jóvenes porque nunca debe envejecerse la memoria de las mercedes recibidas; y como estas deben hacerse exentas de miras interesadas; por eso se representan desnudas las tres hermanas: se dan los brazos porque los hombres deben ayudarse mutuamente. En fin son tres, y significan la dádiva, la admisión y el agradecimiento. Les daban por atributo una rosa, un ramo de mirto y un dado, y esto da a entender que la beneficencia simbolizada por las tres Gracias es una virtud tan bella como la rosa; que la memoria de los beneficios deber ser permanente como el mirto, que conserva mucho tiempo su verdor, y que debe ser correspondida con gratitud [...] Como personajes mitológicos expresan los atractivos de la hermosura, y así se les da la rosa y el mirto, plantas que se atribuyen a Venus; y el dado es símbolo de los sencillos juegos de la infancia.

Y aquí encontramos el segundo de los sentidos que nos ofrece la tríada de Venus: Las Tres Gracias, una imagen ejemplo de la Liberalidad.

Séneca explica este argumento y nos apunta la razón de su tradicional composición artística. En su tratado Sobre los beneficios propone la iconografía de las Tres Gracias para entender las buenas relaciones humanas. Nos habla de la generosidad y liberalidad, también una buena práctica en los argumentos

28. Conti, Mitología, p. 293.

29. Fabre, F. J.: Descripción de las alegorías pintadas en las bóvedas del Real Palacio, Madrid, 1829, p. 180-181. 


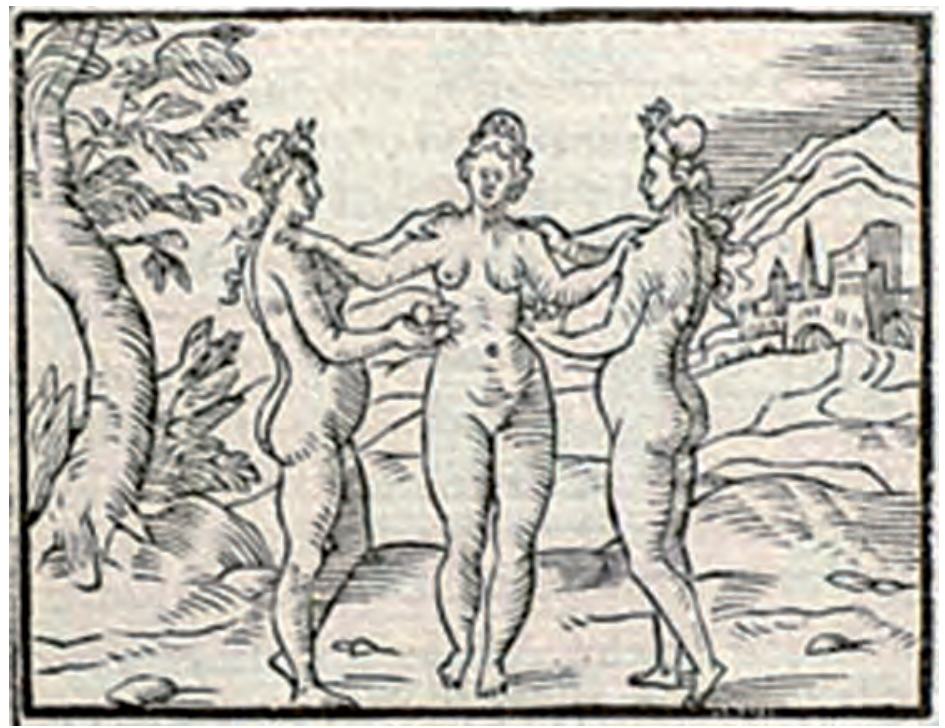

Fig. 20. Emblema de Coustau, Las Gracias (1560)

del amor. Las Gracias representan las tres acciones que son el fundamento de nuestra vida social: dar, recibir y devolver. Esta misma lectura se establece en los Emblemas de Coustau, quien presenta las Tres Gracias para precisar que por ellas los poetas nos han legado el más grandioso monumento que toda sociedad debe conservar entre las relaciones humanas y no es otro que la liberalidad: dar, recibir y devolver [Fig. 20]. ${ }^{30}$

El filósofo español afirmaba que la cuestión clave en la vida es que aprendamos a comportarnos en este sentido. Añade que las Tres Gracias eran más hermosas que las Horas y que fueron dadas por compañeras a la diosa Venus. Explica por ellas cuestionándose:

Pregunto pues: Por qué Gracias son tres y que son hermanas y que están asidas de las manos; Por qué las pintan mozas y de tierna edad y vírgenes con la vestidura clara, suelta y transparente.

A esto dicen algunos que han de ser tres; porque la una representa al que hace la buena obra; la otra al que la recibe; y la otra al que la gratifica y vuelve [...] Risueñas las pintan porque dicen que los que tratan en esta mercaduría traen el rostro muy alegre como se ve así en el que da como en el que recibe. Píntanlas jóvenes porque no ha de envejecer la memoria de las buenas obras. Vírgenes porque son incorruptibles. Sencillas para todos y que no han de tener punta de obligación y deuda, sino libre donación. La vestidura suelta y clara porque las buenas obras quieren ser vistas (De Beneficiis L.I). 
Valeriano recurre a Séneca para explicar el sentido de las Gracias en su Libro I, capítulo XLVIII [Fig. 21]. También Alciato presenta en el cuerpo de su emblema CLXII a las Tres Gracias con similar contenido al ofrecido por el filósofo hispano [Fig. 22]:

[...] Quien mucho da, quedándose desnudo./ Por qué les dan señal de ligereza?/ ¿Porque dos veces dio quien presto pudo/ Dar lo que había de dar, que el don que tarda/ Poco se estima por ser tardo y rudo./ ¿Por qué vuelta de espaldas se reguarda/ la una de ellas? El agradecido/ De aquello que agradece mas aguarda./ Que aquello que en pagar ha desprendido/ Las otras dos que quedan se lo pagan [...].

En dos de los emblemas de Meyer se toma como cuerpo a esta tríada para su tratado Parvus Mundus. Por ellas nos dice que la liberalidad del hombre agrada a Dios [Fig. 23]. ${ }^{31}$ Sigue a Pablo en la epístola a los Hebreos para señalar $(13,16)$ :

Y de hacer bien y de la ayuda mutua no os olvidéis; porque de tales sacrificios se agrada Dios.

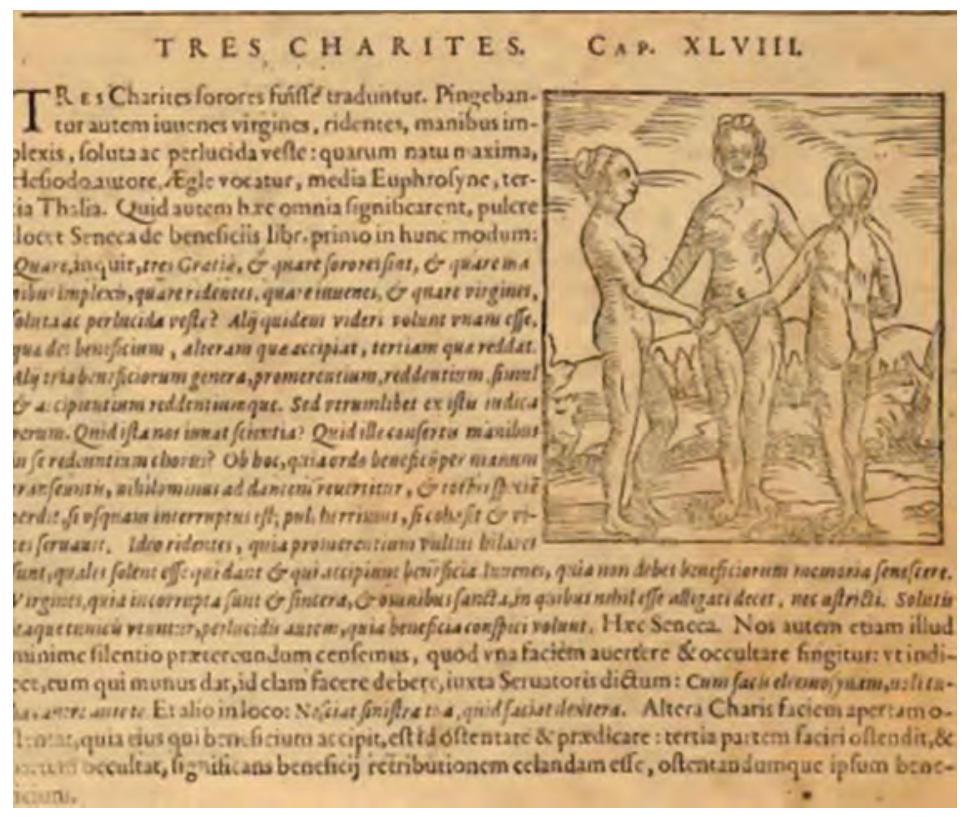

Fig. 21. VAleriano, Hieroglyphica, Las Gracias

31. MeYer, M.: Homo microcosmus, hoc est: parvus mundus, macrocosmo, id est: magno mundo, in variis ari incisis figuris totq; carminibus Latinis, per selectiores veterum poëtarum fabulas, nec no elegantiores quasdam historias, emblematice expositus; cujus hoc editio tertia. In qua Latina ista carmina puris rhythmis, Germanicis sunt donata ... Opus, non solùm ad studiosa juventutis, sed etiam pictorum, sculptorum ... usum et delectationem adornatum., Primera edición en latín editada en Amberes en el año 1579. Edición consultada Frankfurt, 1670, pp. 36-39. 


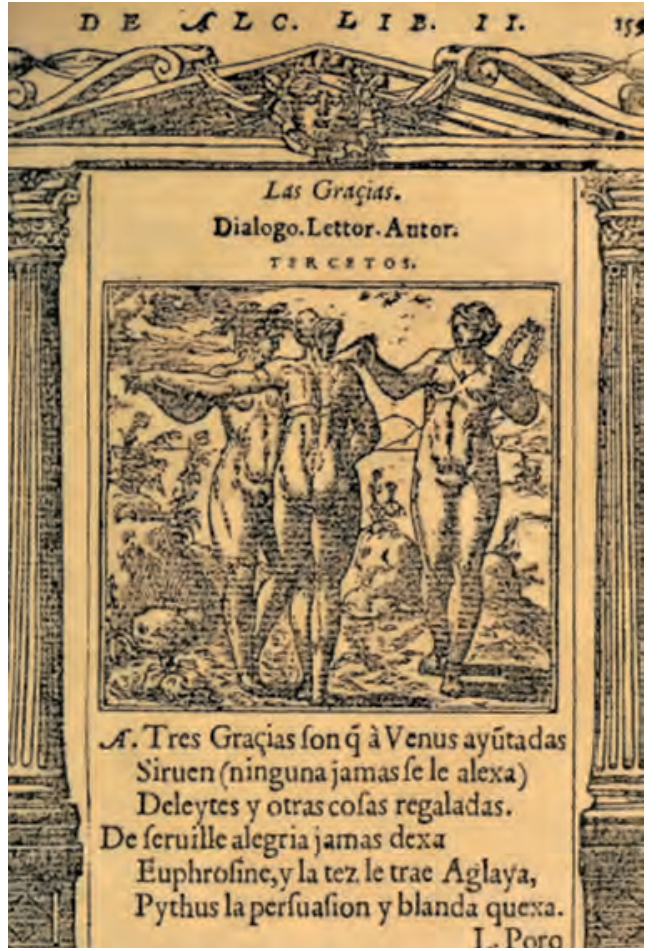

Fig. 22. Alciato, Las Gracias, Emblema CLXXII (1531)

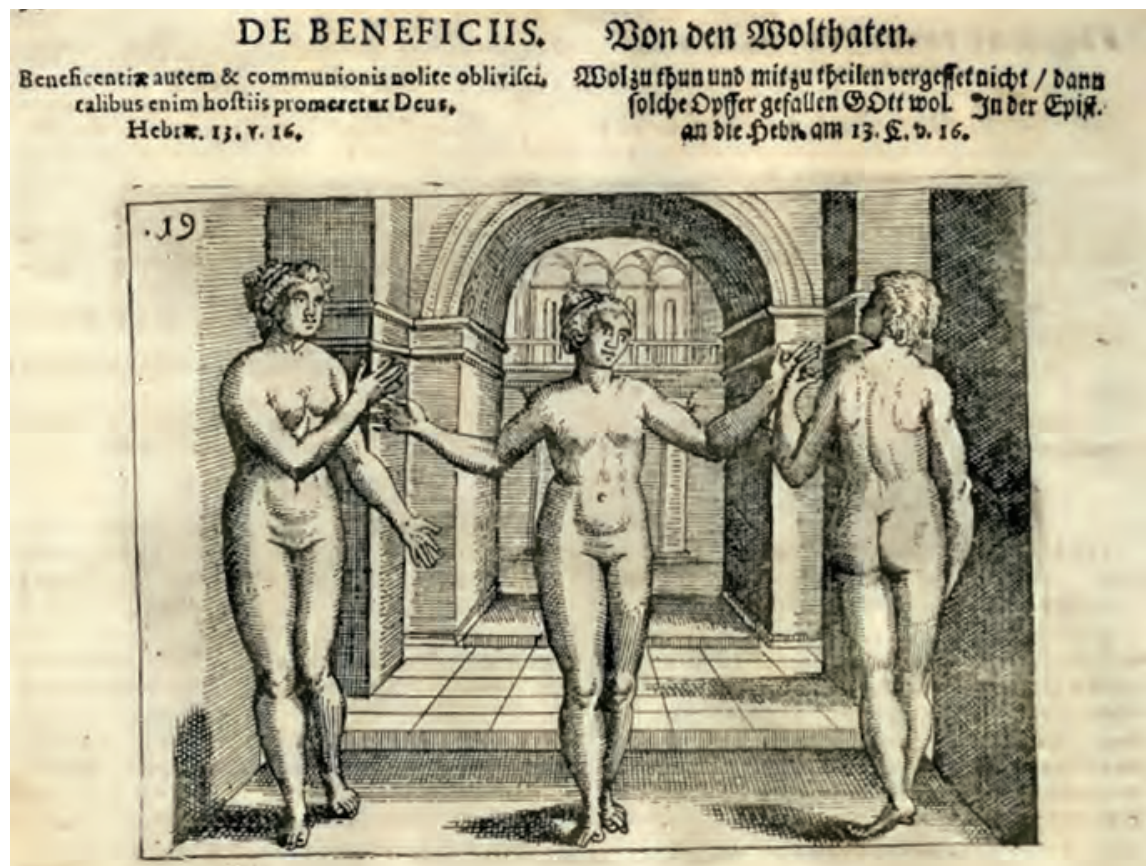

Fig. 23. Las Gracias, Parvus Mundus (1579) 
En este sentido no extrañará que la idea se convirtiera en todo un aviso para príncipes quienes, como precisaba Saavedra Fajardo en su Empresa XL, en todo momento su comportamiento ha de ser liberal que no pródigo.

\section{A MODO DE CONCLUSIÓN}

Sin duda estas «poesías» que compusiera Rubens convierten al artista en claro pintor de la metáfora. La filosofía estoica incidió de manera notable entre los humanistas nórdicos del siglo Xviı y la huella de Vaenius en el pintor de Amberes así lo refiere.

Dos pinturas hemos considerado, una en expreso encargo para el monarca Felipe IV, la otra adquirida por el gobernante tras la muerte del artista.

Por la primera, el Juicio de Paris, sería ingenuo considerar el argumento en una mera recreación estética o literal de la fábula. Los sentidos que manifiesta han de ser considerados conforme a los criterios que tanto los mitógrafos como los emblemistas plantean en el argumento: una visión del gobierno centrada en el dominio de la razón sobre los placeres mundanos. El pensamiento converge con el estoicismo y los postulados de Epicteto convirtiendo la poesía visual en claro pensamiento político.

El segundo de los lienzos en nuestro comentario nos ofrece a las Tres Gracias, compañeras inseparables de la diosa Venus que explican la dimensión del amor en el contexto de los pensadores neoplatónicos del siglo xvi como un goce -moderado- de la belleza. El sentido estoico ofrece otros parámetros pues considera por la tríada una imagen del buen desarrollo en las relaciones humanas y políticas donde, el gobernante, siempre en su liberalidad ha de procurar el verdadero beneficio para su pueblo. 